\title{
EDDIE - 3D SZKENNELÉS ÉS KITERJESZTETT VALÓSÁG OKTATÁSI CÉLRA
}

\section{EDDIE - 3D SCANNING AND AUGMENTED REALITY IN EDUCATION}

\author{
Juhász Csaba ${ }^{1}$, Muhi Kristóf,, Johanyák Zsolt Csaba ${ }^{3}$ \\ Neumann János Egyetem, GAMF Müszaki és Informatikai Kar, Informatika Tanszék, Kecskemét, Magyarország \\ 1 juhaszcsaba23@gmail.com \\ ${ }^{2}$ mkristof@outlook.com \\ 3 johanyak.csaba@gamf.uni-neumann.hu
}

\begin{abstract}
We are convinced that the learning process could be a lot more interesting and more interactive for the young people with the help of modern technologies. The presence and the usage of the smartphones is natural for today's young generations, although they do not use their inherent potential for example for educational purposes. Eddie is a hybrid of a smartphone application and a school book. The school book would keep its original form, but we would make the application fit for the given subject. The already existing pictures in the schoolbooks would work as a special indicator, which our application could read. The application would show different contents virtually in AR (Augmented Reality), based on the scanned image. The shown content could be a 3D model, animation or video.
\end{abstract}

Keywords: education, augmented reality, digital education, smartphone, application.

\section{Összefoglalás}

Meggyőződésünk, hogy a modern technológiák segítségével a tanulási folyamat sokkal érdekesebb és interaktívabb lehet a tanulók számára. Az okostelefonok jelenléte és használata már természetes a mai fiatal generáció számára, de a benne rejlő potenciált nem használják ki olyan területeken, mint például az oktatás. Az Eddie egy okostelefonos alkalmazás és egy iskolai tankönyv együttese. Míg az iskolai tankönyv megőrzi formáját, az alkalmazás az adott témához illeszthető. A már meglévő képek a tankönyvekben különleges indikátorként müködnek, amelyet az alkalmazásunk képes felismerni. A felismert, fizikailag is jelen lévő képekre így a mobiltelefonunk kijelzőjén látva képesek vagyunk kiterjesztett valóság (AR - augmented reality) segítségével megjeleníteni különböző 3D-s objektumokat. A megjelenített tartalom lehet 3D-s modell, animáció vagy videó.

Kulcsszavak: oktatás, kiterjesztett valóság, digitális oktatás, okostelefon, alkalmazás.

\section{Előzmények}

\subsection{A kiterjesztett valóság}

A kiterjesztett valóság (Augmented Reality, AR) a valóság egyfajta virtuális módon történő kibővítése. A technológia gyakorlati használatához szükségünk van egy kamerával és megfelelő hardverrel ellátott okostelefonra vagy egy erre a célra kifejlesztett szemüvegre.
Ezen eszközök használatával képesek vagyunk a céleszköz valós idejű kameraképén keresztül, a valós környezetbe különböző virtuális elemeket vetíteni.

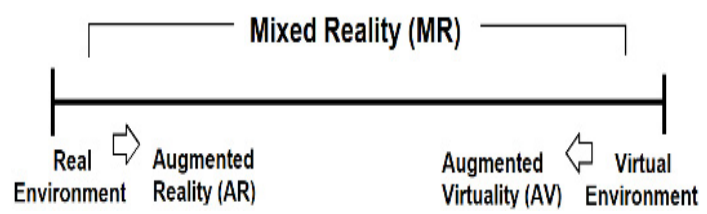

1. ábra. A kevert valóság kategorizálása [1] 
A kiterjesztett valóság megvalósítások alapvetően két nagy csoportba sorolhatóak a virtuális elem helyzetét meghatározó algoritmus és a megjelenítési mód függvényében.

Az egyik a pozíció és irány alapú AR. Célja, hogy a kijelzőn a már meglévő valós idejű kameraképet valamilyen plusz információval egészítse ki. Ezeket az információkat úgynevezett POI-k (Point of Interest) tartalmazzák. Ezek olyan pontok helyét tárolják, melyek a felhasználó számára érdekesek, hasznosak lehetnek. A képernyőn megjelenő információk pontos helyének meghatározása a GPS pozíció, a beépített iránytű és a gyorsulásmérő adatainak feldolgozásával történik meg.

Az AR másik típusa a marker alapú AR. Ilyenkor egy speciális jelölőt (általában képet, képrészletet) keresünk. A marker (indikátor) pozíciója és helye meghatározható az okostelefon valós idejü kameraképe által, ezáltal tetszőleges virtuális objektumokat helyezhetünk rá. Alkalmazásunk müködése is ebbe a kategóriába sorolható.

\subsubsection{Történeti áttekintés}

Ivan Sutherland 1968-ban [2] fejlesztette ki az első fejre erősíthető képernyőrendszert. A rendszer képes volt különböző wireframe (hálóterves) grafikák megjelenítésére.

1974-ben Myron Krueger megépítette a Videoplace [3] nevü laboratóriumot, mely különböző kivetítőkkel és kamerákkal képes volt élethű sziluettek szimulálásra, körülvéve a felhasználót számos interaktív kezelőfelülettel.

Számos kutatást és fejlesztést követően a következő mérföldkő 1990-re tehető, amikor Tom Caudell megalkotja az Augmented Reality (AR) kifejezést [4]. 1992-ben Louis Rosenberg kifejleszti az első működőképes AR rendszert az amerikai légierőnek [5], különböző gépek virtuális vezérlésének céljából. 1994-ben Julie Martin rendezi meg [5] az első kiterjesztett valóságot is körül ölelő színházi produkciót melyben akrobaták egy virtuális objektumot táncoltak körül a színpadon.

A 2000-es évek kezdetétől a kiterjesztett valóság felhasználási területe nagy mértékben teret nyert a szórakoztató iparban. Először 1998-ban a Sportvision televízió csatorna NFL játékában [6] használtak vizuális jelölőt a meccs különböző elemeinek kiemelésére.

A hadiparban folyamatosan fejlesztések folytak különböző vizuális segédeszközök terén, főleg a légierőben. Hirokazu Kato kifejleszti az ARTool-Kit-et [7], mely egy nyilt forráskódú programkönyvtár. Segítségével képesek vagyunk különböző számítógépes grafikák valós kameraképen való megjelenítésére és annak követésére. 2009-ben az ARToolKit már webes böngészőket is támogat.

Napjainkban a hardver és szoftver rohamos fejlődésével egyre közelebb kerülnek a valósághű AR élmények. A nagy számítástechnikai cégek mind kiemelten foglalkoznak a technológiával. A Microsoft HoloLens [8] szemüvege külső hardver igény nélkül képes AR-tartalmat megjeleníteni, akár jelölők nélkül, a tér és a síkok érzékelésével. Az Apple és Google, a két legnagyobb okostelefon operációs rendszert az iOS-t és Androidot fejlesztő cég is rendelkezik saját AR fejlesztőkörnyezettel, melyekkel lehetőségünk van létrehozni a kiterjesztett valóság élményét.

\subsubsection{Felhasználási lehetőségek}

Mint ahogyan arról az előző fejezetben már szót ejtettünk, a kiterjesztett valóság első felhasználási területét a sportközvetítések jelentették. Labdarugó mérkőzések kezdetekor a pályára vetített csapat címerek, kajak-kenu esetén a célba éréskor virtuálisan meghúzott jelzővonal is ezt a technológiát használja. Marketingtevékenységben is kiválóan használható, ahogyan a turizmusban az irány alapú AR adta lehetőségek által bővebb információkat kaphatunk a minket körülvevő városról. Egyéb felhasználási módok a teljesség igénye nélkül: egészségügy, ipari folyamatok (gyártás és javítás), szórakoztatás, oktatás, játék stb.

\section{Az Eddie alkalmazás tervezési szem- pontjai}

Az alkalmazás célja, hogy a hagyományos értelemben vett oktatási folyamatot kiegészítse, és egy interaktív, élményalapú segédeszközt nyújtson a tanulásban. Az alkalmazás különböző digitális tartalmakat (elsődlegesen 3D objektumokat) képes megjeleníteni a felhasználó okoseszközén (okostelefon, táblagép) az AR technológia használatával.

Az AR megjelenítés erősen eszközfüggő, ezért a megfelelő fejlesztőkörnyezet kiválasztása kulcsfontosságú feladat volt. Az alkalmazás másik kulcsfontosságú tervezési szempontja az volt, hogy a tanárok és diákok számára is egyszerűen használható legyen, tehát: ne kelljen plusz eszközt vásárolni (AR szemüveg), az alkalmazás könnyen elérhető és telepíthető legyen. A tanárok szempontjából a 3D tartalom előkészítése (kollekciók létrehozása) nem szabad, hogy megterhelő legyen. 


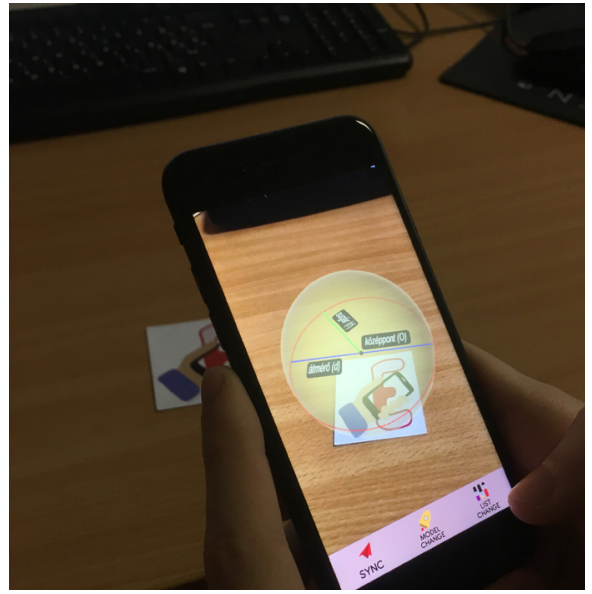

2. ábra. Az Eddie alkalmazás müködés közben

\subsection{Fejlesztőkörnyezet kiválasztása}

\subsubsection{AR fejlesztő könyvtárak}

Az AR technológia rohamszerü fejlődésének eredménye, hogy már nem szükségesek felsőkategóriás eszközök a megjelenítéshez, így egyre jobb élményt lehet nyújtani az átlagos eszközökkel rendelkező felhasználóknak is. Az alkalmazás tervezésekor azt a cél tűztük ki, hogy nem korlátozzuk az eszközöket, minél több felhasználónak elérhető szeretnénk tenni.

Ez a megfelelő fejlesztői környezet kiválasztásakor volt fontos.

A következőkben három AR fejlesztő könyvtárat szeretnénk kiemelni.

\subsubsection{ARCore}

Az ARCore [9] a Google által fejlesztett AR-megjelenítő SDK (software development kit, szoftverfejlesztői csomag) melynek első verziója 2018. március 1-én jelent meg.

Három technológiát használ a digitális tartalom megjelenítéséhez: mozgáskövetés, környezetfelismerés (síkok, padló felismerés) és a környezeti fények feldolgozása. Használatához Android 7.0 (Nougat) vagy későbbi rendszer szükséges.

Apple iOS rendszeren 11.0 vagy későbbi frissítés a követelmény. Az operációs rendszer mellett eszközfüggőség is van: Az ARCore kizárólag az Apple iPhone SE vagy újabb (kb. 15 különböző) eszközökön müködik. Az Android rendszerű okostelefonok terén jelenleg csak kb. 100 eszköz támogatott a több mint 21700 különböző [10] okostelefon közül.

Az erős eszközkorlátozás miatt az előzőekben taglalt fejlesztési szempontoknak az ARCore könyvtára nem felelt meg.

\subsubsection{ARKit}

Az ARKit [11] egy az Apple által fejlesztett AR-megjelenítő könyvtár, melynek első stabil verziója az iOs 11 megjelenésével egyidőben, 2017. júniusában jelent meg.

A könyvtár kizárólag iPhone és iPad eszközökkel kompatibilis. Szoftver- és hardverfüggőség itt is jelen van, ahogyan az ARCore-nál: iOS 11 vagy újabb rendszer és iPhone SE vagy attól újabb eszköz szükséges a futtatáshoz. Technológiailag az iPhone hardveres megoldásait használja, köztük a VIO-t (Visual Inertial Odometry) mely a környezet észleléséért felel (síkok-, tárgyak-, padló felismerése). Az ARCore-hoz hasonlóan képes feldolgozni a külső fényforrásokat a még szebb vizuális megjelenítés céljából.

Ahogyan a Google ARCore függőségei, az ARKit kizárólagos iOS támogatása végett ez a könyvtár sem felelt meg az alkalmazás fejlesztési követelményeinek.

\subsubsection{Vuforia}

A Vuforia (korábban QCAR) a Qualcomm által fejlesztett AR fejlesztői platform, melynek első stabil verziója 2011. áprilisában jelent meg [12]. Marker alapú AR fejlesztésére használható SDK. Szoftver- és eszközkorlátozása az előzőekben taglalt ARCore és ARKit-hez képest jóval kedvezőbb, Android és iOS rendszereken is csak szoftverfüggősége van: Android 4.4-es verziótól, illetve iOS 9.0-tól újabb verzió szükséges. Rendelkezik egy úgynevezett Vuforia Cloud rendszerrel, mely lehetőséget biztosít arra, hogy valós időben változtassuk a markereket és a hozzá rendelt, kiterjesztett valóságban megjelenő 3D tartalmat.

Az előzetes fejlesztési szempontokat figyelembe véve, a Vuforia széles eszköztámogatása és felhő-alapú rendszere miatt erre a könyvtárra esett a választásunk.

\subsection{A 3D szkennelés}

A 3D szkennelést főleg akkor alkalmazzák a feladat hatékonyságának javításában, amikor nem egyszerü geometriai modellről van szó, hanem egyszerü geometriai elemekből nem felépíthető modellről. Ekkor a szkennelt modell egyfajta háromdimenziós sablonként szolgálva megkönnyíti a mérnökök munkáját, valamint egy már kész módosítható modellként is lehet már rá tekinteni. A szkennelés végeredményeként létrejövő 3D modell lehet textúrázott vagy textúra nélküli mesh (pontháló) [13]. Egy emberi test szkennelése körülbelül 5-15 percet vesz igénybe a szükséges útmutatással együtt. Az effektív szkennelési fo- 
lyamat körülbelül 2-3 perc. Tárgyak szkennelése esetén a folyamat több nap is lehet, amennyiben a tárgyat újra kell modellezni.

A 3D szkennelés célja, hogy egy olyan pont-felhőt kapjunk, amely alkalmas a 3D modell létrehozásához, metszetek készítéséhez, pontos dokumentáláshoz, rekonstrukcióhoz, mérések elvégzéséhez, 3D nyomtatás előkészítéséhez, szabálytalan alakzatok térfogatszámításához.

Leggyakoribb felhasználási területek:

- építészet;

-iparialkalmazás (jármű-, gép-, eszközgyártás);

- reverse engineering (mérnöki rekonstrukciós visszafejtés).

Az általunk beszkennelt testek (biológia szertári modellek) feldolgozása során a „reverse engineering” folyamatát követtük végig.

\subsection{Reverse engineering (mérnöki rekonst- rukciós visszafejtés)}

A reverse engineering egy olyan eljárás, amelylyel egy olyan kész objektumhoz készítünk tervet, ami nem rendelkezik tervdokumentációval, nincs számítógéppel elkészített terve, műhelyrajza, kézzel formázott mesterminta, bonyolult formájú tárgy vagy illeszkedő alkatrész.

A reverse engineering folyamata:

- fizikai modell digitalizálása;

-mérési pontok szerkesztése;

- mérési pontok beolvasása CAD rendszerbe;

- pontokra felületi görbék illesztése;

- görbékre felület vagy felületsík illesztése;

- felesleges részek eltávolítása;

- modell pótlása, szerkesztése;

- modell gyártása;

-mérés.

\section{Következtetések}

Dolgozatunk készítése során feltérképeztük a kiterjesztett valóságot megvalósító fejlesztői könyvtárak és a 3D szkennelés adta technológiai előnyöket és hátrányokat. Kutatásaink és kísérletezéseink során megtapasztaltuk, hogy az általunk használt Sense3D szkenner [14] alacsony részletességi szintje miatt nem használható univerzális célokra. A kiterjesztett valóság szoftverés hardverfüggősége a jól megválasztott, Vuforia $A R$-megjelenítő könyvtár esetén is jelentős teljesítménybéli eltéréseket mutat a különböző teljesítményű okostelefonoktól függően.

Az alkalmazás továbbfejlesztésének szempontjából elsősorban a végfelhasználók visszajelzésére lenne szükségünk. E célból szeretnénk olyan workshopokat, találkozókat szervezni, ahol a diákok és a tanárok is interaktívan kipróbálhatják az alkalmazást és valós visszajelzéseket tudnak adni.

A 3D szkennelés minőségi javítása is fontos cél a megfelelő élmény átadásának szempontjából.

\section{Köszönetnyilvánítás}

Köszönettel tartozunk a kutatás támogatásáért, amely az EFOP-3.6.1-16-2016-00006 „A kutatási potenciál fejlesztése és bővítése a Neumann János Egyetemen” pályázat keretében valósult meg. A projekt a Magyar Állam és az Európai Unió támogatásával, az Európai Szociális Alap társfinanszírozásával, a Széchenyi 2020 program keretében valósul meg.

\section{Szakirodalmi hivatkozások}

[1] Milgram P., Takemura H., Utsumi A.: Augmented Reality: A class of displays on the reality-virtuality continuum. Proceedings of Telemanipulator and Telepresence Technologies, 1994

[2] Colocation America, The history of augmented reality. (2018-11-04)

https://www.colocationamerica.com/blog/history-of-augmented-reality

[3] The Digital Age, Myron Krueger Biography http://thedigitalage.pbworks.com/w/ page/22039083/Myron\%20Krueger (2018-11-04)

[4] AR at Boeing (1990) (2018-11-04) http://www.idemployee.id.tue.nl/g.w.m.rauterberg/presentations/hci-history/tsld096.htm

[5] Infographic, The History of Augmented Reality http://www.augment.com/blog/infographic-lengthy-history-augmented-reality/ (2018-11-04)

[6] Sports Illustrated, Behind the NFL's yellow first down line, and what's next for sports TV

https://www.si.com/edge/2015/01/29/behind-nfl-yellow-first-down-line-sportsvision-technology (2018-11-04)

[7] Apple Developer, ARToolKit (2018-11-04) http://www.hitl.washington.edu/artoolkit/

[8] Microsoft, HoloLens. (2018-11-04) https://www.microsoft.com/hu-hu/hololens

[9] Google, ARCore. (2018-11-04) https://developers.google.com/ar/

[10] Android supported devices list. (2018-11-04) http://storage.googleapis.com/play_public/supported_devices.csv

[11] Apple Developer, ARKit. (2018-11-04) https://developer.apple.com/arkit/

[12] Vuforia AR Engine. (2018-11-04) https://www.vuforia.com/

[13] Freedee, A non-kontakt 3D szkennerek helye a gyártásban

http://www.freedee.hu/a-non-kontakt-3d-szkennerek-helye-a-gyartasban/ (2018-11-04)

[14] iDig, Sense 2 3D scanner. (2018-11-04) https://www.idig3dprinting.co.uk/shop/brand/ sense-3d-scanner 